\title{
The Research on the Feasibility of Offering the Optional Course of Taekwondo in Universities
}

\author{
Liling Zeng ${ }^{\mathrm{a}}$, Shumei $\mathrm{Yi}^{\mathrm{b}}$ \\ Pingxiang University, Jiangxi 337055, China \\ a631588752@qq.com, b340466055@qq.com
}

\begin{abstract}
In the background of sunshine sports, selection of College PE courses in the teaching content must meet the needs of students in sports, it is necessary to introduce Taekwondo to the curriculum construction, further enrich the teaching content of college sports, to provide many kinds of sports for students to lay a solid foundation for the cultivation of students' consciousness of lifelong sports and habits.
\end{abstract}

Keywords: Taekwondo, elective course, feasibility, University.

\section{Introduction}

Taekwondo has been listed as an official event since the Olympic Games in 2000, it has been recognized by the people of the world, and get further development in the world. It is a fashionable and practical sports, in addition to highly ornamental, but also has very strong practicability, with physical fitness, unique role the self-defense and physically and mentally. In recent years, the State Sports General Administration has also given a "special policy" in Taekwondo project, requirements developed rapidly. At present, the public sports curriculum in Colleges and universities in China have opened the sports forms, for college students to choose according to their own preferences for PE. Therefore, the establishment of Taekwondo elective course in college physical education is not only the need of teaching reform, but also the requirement of educational innovation. On the one hand to provide new sports items for the students, to improve students' interest in learning sports skills, on the other hand, it is also the need to achieve all-round development of talents

\section{The introduction of Taekwondo}

\subsection{The origin and development of Taekwondo}

Taekwondo originated in North Korea, called taekkyeon or hwarangdo. In 688 ad, in the kingdom of Xinluo after the reunification of the Korean, founded the "hwarangdo", as a special form of organization, its purpose is to select a group of young people of $\mathrm{Wu} \mathrm{Yi}$ aspects of learning, and cultivate loyalty to the ruling class about filial piety, brave, fearless warriors. During the two World War, the Korean Peninsula's self-defense also gained popularity and development, 1955 North Korea will be changed to "self-defense Taekwondo". Taekwondo was listed as a demonstration project in the 1988 Olympic Games, and in 1992 began to be a test competition project, September 4, 1994 was officially held for the Sydney Olympic Games.

\subsection{The classification of Taekwondo}

Taekwondo is mainly divided into two categories. And Taekwondo Taekwondo, the main purpose is to defeat the enemy, to defeat the other side as the goal. Techniques include basic footwork, leg, the combination of technologies, competition rules and tactics, exquisite action competitive technology and practicability; and Taekwondo is to improve the health and entertainment exchange, by Poomsae, athletic skill test, culture, and stunt self-defense components, people pay attention to the cultivation of the strong willpower and so honour the teacher and respect his teaching literacy.

\subsection{The characteristics of Taekwondo}

With both hands and feet, with legs is the main feature of Taekwondo. Taekwondo in the leg technology accounted for more than $70 \%$ of the overall technology. Whether it is in the game or in 
actual combat, the attack method is very simple and Taekwondo effectiveness. At the same time also pay great attention to the beginning of Taekwondo final ceremony and always will be "ceremony" as the contents of training, pay attention to the "ceremony beginning end ceremony" salute to cultivate and nurture habits.

\section{The effect of Taekwondo on College Students}

\subsection{Enhance the physical health of College Students}

The technology of Taekwondo movement require practitioners to reach a certain power and speed requirements, body coordination, long time practice system can make the muscles and stimulate the strength, at the same time can consume excessive fat in the body, build a good body shape. In addition, taekwondo also have higher requirements on the reaction rate. Have a good effect on College Students' sensitivity, but also can improve the students' attention to things.

\subsection{Improve the social adaptability of College Students}

In the process of training of Taekwondo, both personal practice techniques and peer practice. Therefore, everyone should have mutual cooperation and mutual help consciousness. In practice personal technology took each foot target, support each other; in practice, but also to encourage and cheer each other between players in such an environment. People not only cultivate the people's awareness of cooperation, but also improve the ability to interact with others, to lay a good foundation for a good future to the society.

\subsection{Beneficial to the mental health of College Students}

College students pressure often comes from learning, employment, love and so on, mental health problems affect the quality of the quality education of college students. Taekwondo as a new sports items are, as students bad mood to vent window, by practicing taekwondo, and help them to vent emotions, resolve heart pressure and conflict. Beneficial to their mental health.

\subsection{Can develop the intelligence level of College Students}

A certain amount of sports can promote the development of the brain, and improve the intelligence level of Taekwondo. Very practical, a lot of technical movements require practitioners flexible, fast, agile and changeful, in order to maintain the normal function of the brain for a long time, must carry out special training on the nervous system and the sensitivity etc. Therefore, taekwondo can improve college students the observation and observation, improve thinking ability, comprehensive development and intellectual development, to create a good physical condition, but also help to improve the learning efficiency.

\section{The significance of offering optional course of Taekwondo in Colleges and Universities}

\subsection{The need to achieve the goal of personnel training in Colleges and Universities}

The main goal of university education is to cultivate good psychological quality with relevant skills, personality and quality of senior specialized talents. School physical education is an important educational goal to achieve the above commitment, taekwondo can not only promote the physical health of students, cultivate lifelong sports consciousness and habits, and physical and mental pleasure, temper will form a healthy personality, enhance the ability of social communication, there are advantages and role can not be replaced in the cultivation of high quality talents.

\subsection{Conform to the requirements of educational innovation}

The traditional school sports in sports mode, largely restricted to physical education curriculum content, teaching methods, innovation mode and other aspects, it is difficult to realize the overall physical health of college students. Therefore, college physical education should realize the necessity of educational innovate, have certain innovation in sports the project, the introduction of fashion sports, to improve the students' interest in PE.

\subsection{Further improve students' social adaptability}

The university is a turning point for college students to enter the society, students can adapt to the social development directly reflects the quality of higher education. Taekwondo for students not only 
physical health, willpower, personality and other aspects have a positive role in promoting, but also to cultivate students' good manners, etiquette and other aspects of polite also has the obvious function of shape, so that they can better communicate with the people around, and gain their favor.

\section{The feasibility of setting up the optional course of Taekwondo in Colleges and Universities}

\subsection{Taekwondo in Colleges and universities have a certain sense of identity}

Due to the impact of the Olympic Games, especially China athlete Chen Zhong won the Olympic Taekwondo Championship, in China blows up a taekwondo boom. At present, there are more than 2 thousand national amateur Taekwondo training, the number of about 8000000 people. In a survey of college students in more than $70 \%$ of the students understand the sport of Taekwondo, too compare with the project, if the conditions are willing to participate in Taekwondo learning shows that Taekwondo has been most college students of all ages.

\subsection{Colleges and universities to set up a selective course of Taekwondo has a material basis and conditions}

College sports facilities are relatively perfect, all kinds of teaching facilities at a higher level, which provides the material basis for the development of teaching and training of Taekwondo in Colleges and universities. The University also has sports teachers and sports management system is good, can guarantee the quality of teaching Taekwondo.

\subsection{The reform of physical education teaching mode in Colleges and universities needs to add Taekwondo}

In the next round of the teaching reform in Colleges and universities, many school sports have taken "three independent" course selection mode, to improve the students' interest in learning and teaching quality have obvious sports classroom effect. Especially in the background of sunshine sports, many universities in our country are additional Taekwondo projects, to meet the different needs students of different levels.

\section{Colleges and universities to set up the optional course of Taekwondo}

\subsection{Strengthen the training of Teachers}

At present, although the teachers in Colleges and universities in China are relatively strong, but the Taekwondo professionals is still relatively scarce, most are transformed from martial arts teachers, professional background is not much. To hire a professional Taekwondo or high-level retired athletes 6.2 accelerate the construction of teaching materials

The Taekwondo into China is not a long time, most people are still unfamiliar, especially on Taekwondo and basic techniques of judicial rules understanding is not enough. In the university sports curriculum content selection on Taekwondo textbook is only part of the school, to increase the Taekwondo textbook, the relevant rules sport, and technology popularization to the majority of students.

\section{3 speed up the construction of venues and facilities}

Most colleges and universities have set up a Taekwondo Association, but there are few professional equipment of the University, almost no professional venues, students want to learn Taekwondo must go to the community to learn Taekwondo Hall

\section{References}

[1] Song Hua. The Feasibility Study on Offering University Students with TaeKwonDo Curriculum [J]. Anhui sports science and technology. 2006 (27)

[2] Bian Wen Hong. The exploration on the teaching of optional course of Taekwondo in University [J]. Liaoning sports science and technology. 2004 (26)

[3] Tang Ji Yun. Craven implementing happy sports experimental study of [J]. 2010 Journal of Physical Education University Taekwondo Teaching (6) 
[4] Zhang Lei. The problems and Countermeasures in the teaching of Taekwondo in Colleges and universities [J]. Journal of Liaoning Teachers College. 2015 (17) 